University of Nebraska - Lincoln

DigitalCommons@University of Nebraska - Lincoln

Agronomy \& Horticulture -- Faculty Publications

Agronomy and Horticulture Department

7-1942

Role of Seedlings in Recovery of Midwestern Ranges from Drought

J. E. Weaver

University of Nebraska-Lincoln

Irene Mueller

Follow this and additional works at: https://digitalcommons.unl.edu/agronomyfacpub

Part of the Plant Sciences Commons

Weaver, J. E. and Mueller, Irene, "Role of Seedlings in Recovery of Midwestern Ranges from Drought" (1942). Agronomy \& Horticulture -- Faculty Publications. 451.

https://digitalcommons.unl.edu/agronomyfacpub/451

This Article is brought to you for free and open access by the Agronomy and Horticulture Department at DigitalCommons@University of Nebraska - Lincoln. It has been accepted for inclusion in Agronomy \& Horticulture -Faculty Publications by an authorized administrator of DigitalCommons@University of Nebraska - Lincoln. 


\section{ROLE OF SEEDLINGS IN RECOVERY OF MIDWESTERN RANGES FROM DROUGHT *1}

\section{J. E. Weaver and Irene M. Mueller}

University of Nebraska

An extensive survey of the degree of deterioration of midwestern ranges was made in 1939 (Weaver and Albertson, '40). Decreases in the basal cover of the grasses from extreme drought, overstocking, and damage by dust were appalling. Basal cover of the native grass had decreased to 1 per cent in one-fourth of the ranges examined and it was 21 per cent or more in only 16 per cent. Little, if any, improvement occurred during the following year; instead certain large areas suffered distinct losses as a result of severe late summer drought. The perennial grasses over large areas in southwestern Kansas, for example, had been reduced to a basal cover of about 3 per cent in 1937. The cover improved slightly during the two following years, but was reduced to less than 0.5 per cent during the very dry fall of 1939 (Albertson, '41). On some of the better ranges near Syracuse, where the basal cover was about 15 per cent, scarcely a spear of grass remained (figs. 1, 2 and 3).

The drought has now continued (to 1941) with only slight interruptions for eight years. Occasional showers have moistened the soil sufficiently at irregular intervals to promote germination of seeds, including any that may have lain dormant for a long time, but rarely has there been establishment and continued growth of seedlings. Production of viable seed by the native grass has usually been prevented by dry weather following too rapidly a period of flowering. Consequently, it has seemed that the seed supply in the soil might have become greatly depleted and that a single growing season

\footnotetext{
* Contribution from the Department of Botany, University of Nebraska, No. 133.

1 This study was made with the aid of a grant from the Penrose Fund of the American Philosophical Society.
}

would not be sufficient to improve greatly the range as regards the growth of new plants. Exceptions are buffalo grass (Buchloe dactyloides), western wheat grass (Agropyron smithii), and a few other species which have excellent means of propagation by stolons or rhizomes.

Consequently, it was planned, early in the spring of 1941 , to make a survey of the viable seed population in the surface soil of these depleted grasslands. This survey included also drought-damaged true prairie of eastern Nebraska and Kansas. Here, where the mean annual precipitation is 20 inches or more, increase in abundance and vigor of vegetation since the early years of drought ('34'37) has often occurred, but recovery is usually far from complete (figs. 4 and 5 ). Later a quantitative study of the seedling population was also made. Fortunately, 1941 was a year of abundant rainfall and consequently very favorable to seed germination.

\section{Collecting Samples in the Field}

Seeds of range grasses, with rare exceptions, are found on or near the surface of the soil; therefore samples of soil were taken to a depth of 0.5 inch only. Each sample included the top soil of an area of one square foot. It was secured by means of a sharp, flat-bottomed shovel 10 inches in width, which was pushed through the surface soil at 0.5 inch depth to a distance slightly greater than 14 inches. Samples were collected from 49 stations in 28 counties. Except for 13 counties in western Kansas, where 3 samples were taken at each station, five square-foot samples were regularly obtained from each pasture or range. Samples were placed in separate paper sacks, taken to the laboratory, and air dried. 

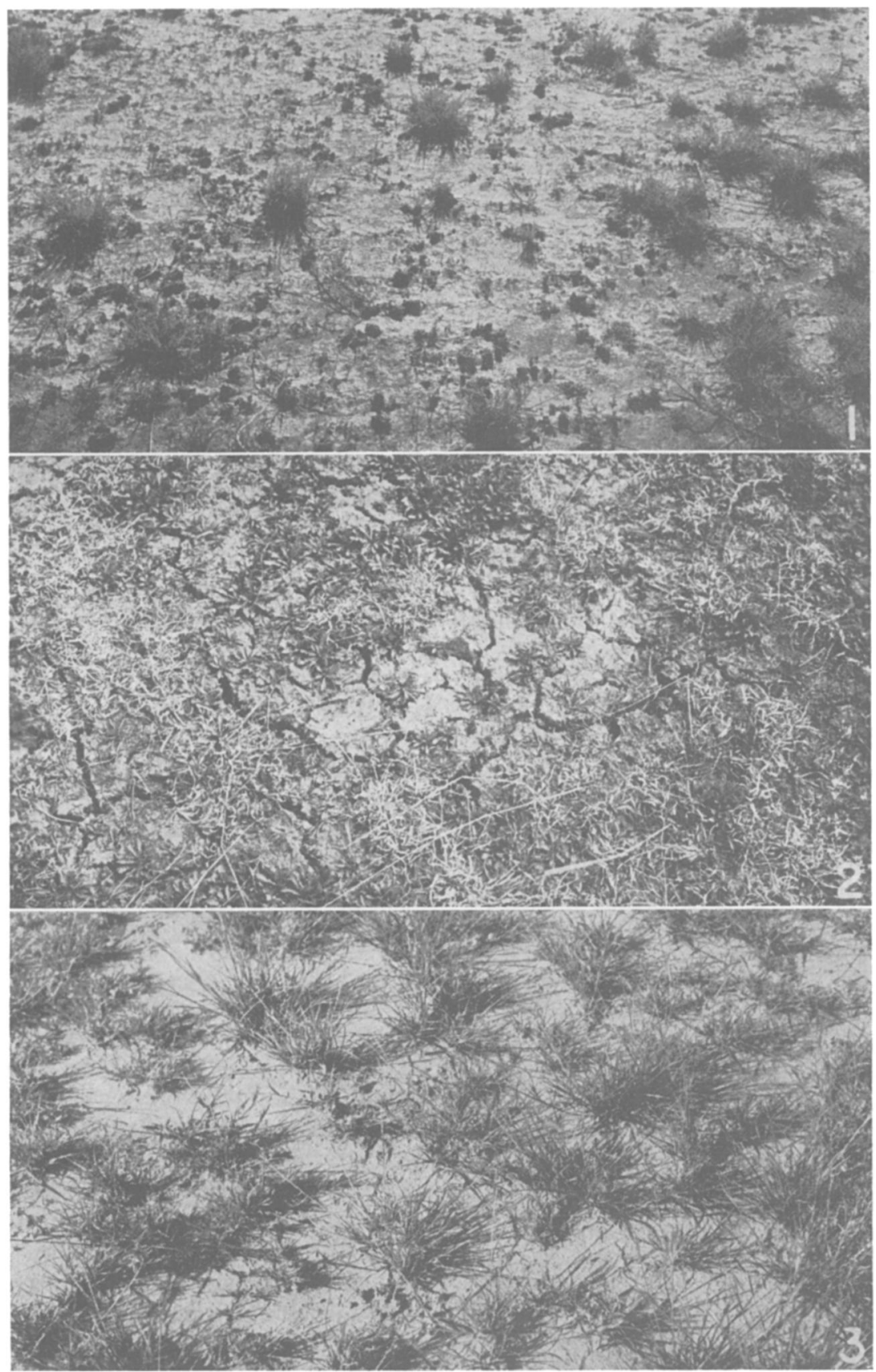

FIG. 1. Range near Syracuse, Kans., showing almost complete destruction of vegetation. Only a few bunches of blue grama grass remain. Photo, August, 1939. FIG. 2. Pasture near Dighton, Kans., showing cracking of soil in layer of dust and rosettes of winter annuals. Photo by Albertson, April 11, 1941. FIG. 3. Detail of range near Cheyenne Wells, Colo., showing small tufts of blue grama and much bare soil. Typical of vast areas in the Great Plains. Photo, June 17, 1941. 

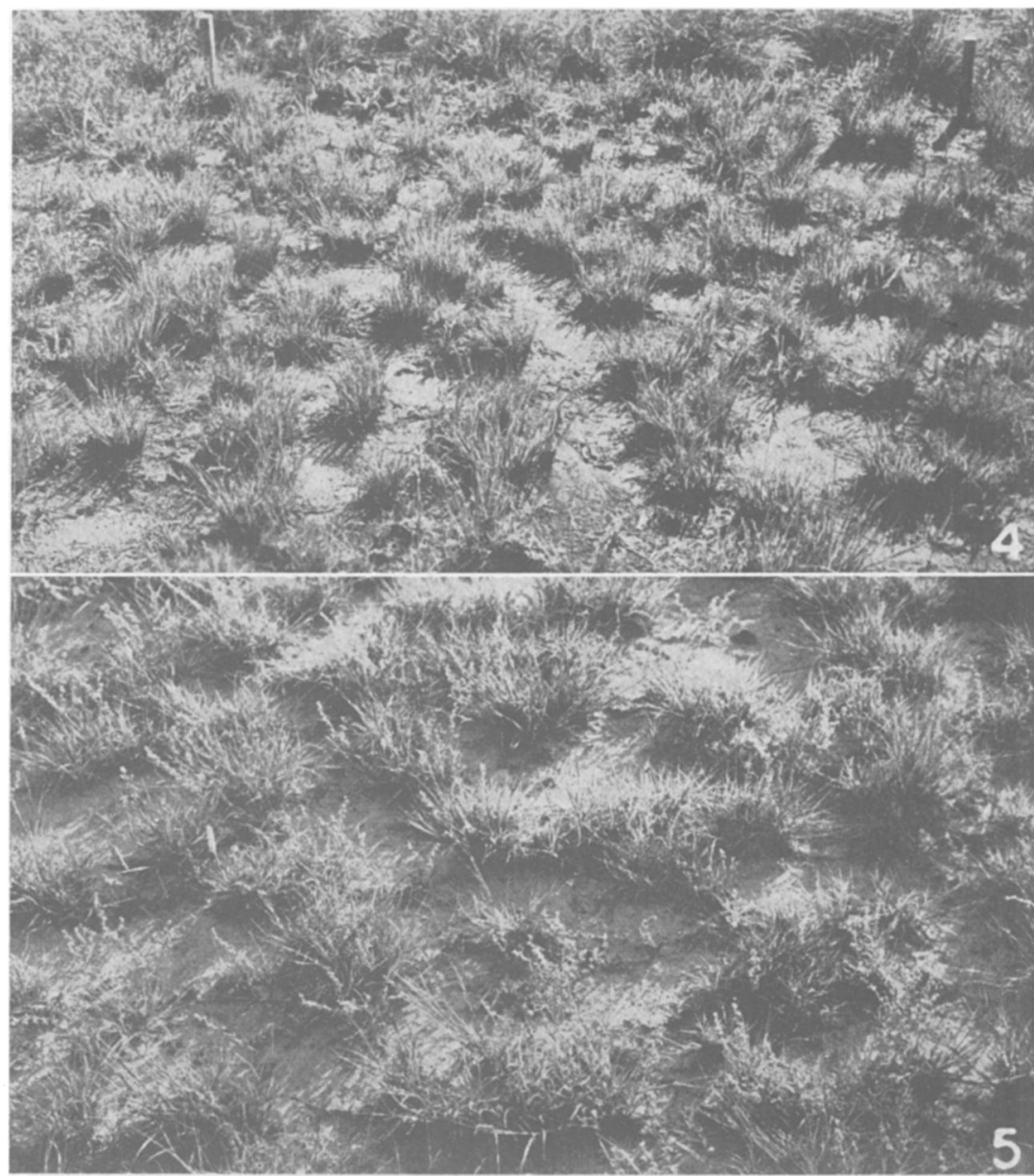

FIg. 4. Prairie near Lincoln, Nebr., with new growth from prairie dropseed and needle grass which had previously been clipped. Note the large amount of soil without cover. This is representative of one of the better drought-damaged prairies. Photo, August, 1940. FIg. 5. A good range near Idalia, Colo. Chief species are blue grama, sand dropseed, and buffalo grass. Note lack of debris on the hard, bare soil.

The wide range of sampling included 7 counties in Nebraska, 4 in eastern Colorado, and 17 in Kansas (fig. 6). Altogether, 196 samples were obtained. Collections were made either late in March or early in April at a time when no grass seedlings were found, although some of the winter annuals, as Lepidium densiflorum and Hordeum pusillum, were an inch or more in height.

\section{Studies on Germination}

Studies on germination were begun with samples of soil from 3 stations
(Lincoln B, Nebraska, Jennings A, Kansas, and Stratton, Colorado) on April 16. The remaining samples were kept air dry until May 27 or 29 . Benches in the greenhouse were cleared and a shallow layer of fine gravel was laid in the bottoms to provide drainage. A layer of sterile sand about 2 inches thick was placed over the gravel, after which the planting area was divided into squarefoot plots by lath partitions. Addition of more sand brought the layer within 0.75 inch of the top of these partitions. Each sample of soil was placed in a separate 


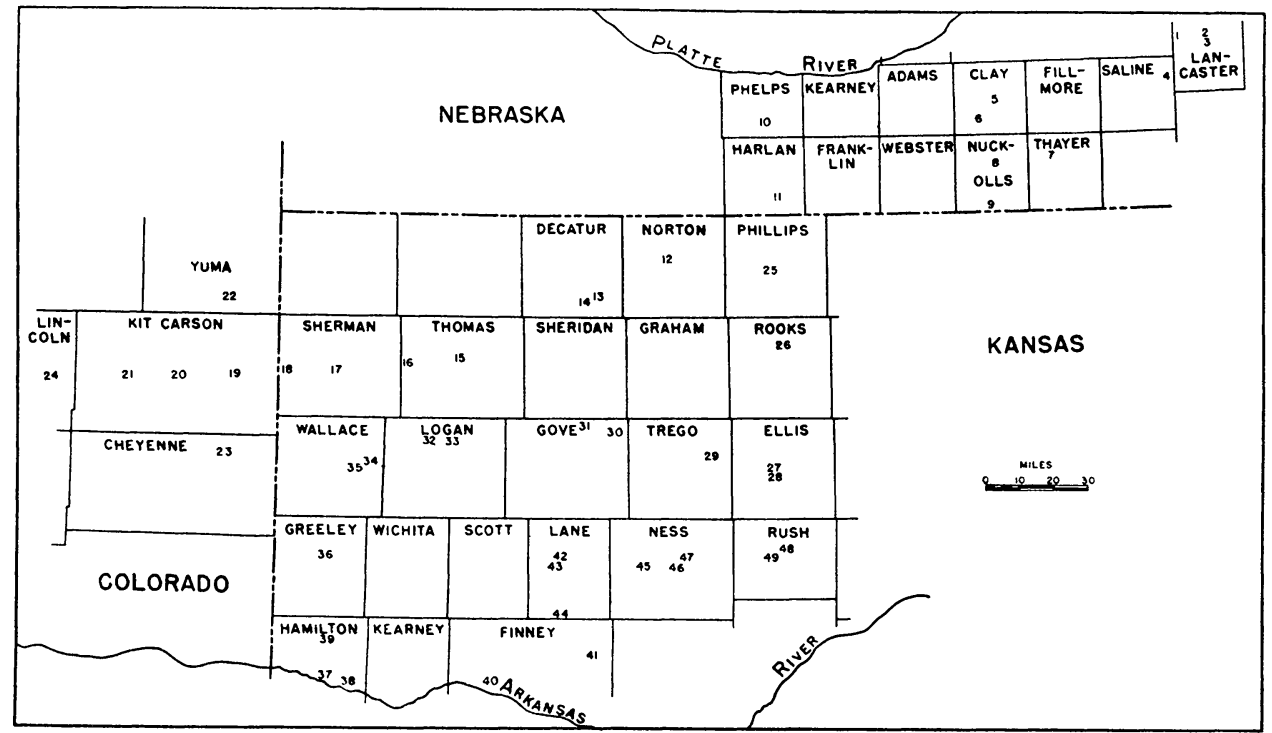

FIG. 6. Counties and station numbers where studies were made. Names of stations are given in table I. Holdrege (10), Alma (11), and Phillipsburg (25) are among the most easterly stations in mixed prairie.

plot, spread to a uniform thickness over the sand, and pressed into firm contact with it. A depth of planting exceeding 0.5 inch to 1 inch has been found detrimental to most grasses (Clements and Weaver, '24; Savage, '34; E. C. Conard ${ }^{2}$ ). Consequently, the soil layer was limited to 0.5 inch to insure germination and emergence of all species. The partitions extended about 0.25 inch above the soil after settling, and thus prevented it from washing from one plot to another when watered. The plots were sprinkled with a fine spray of water as often as there was evidence of drying. The experiment was continued until new seedlings appeared only rarely. About July 1 the soil was allowed to dry, and each sample was lifted into a large pan where it was pulverized and thoroughly mixed. The samples were then returned to their proper plots and treated as before until the end of July.

An environment favorable to germination of seeds was maintained in the green-

${ }^{2}$ Master's thesis, University of Nebraska, 1938. Unpublished. house while the study was in progress. Panels of glass from the end of the house were removed and the opening covered with woven wire, allowing free circulation of air. Light was necessarily reduced somewhat when alternating bands of whitewash were applied to the roof, a procedure which seemed advisable since it resulted in lower day temperatures. Records from a hygrothermograph, operated at about the same level as the plots of soil, showed that prior to July 21 , day temperatures rose above $100^{\circ} \mathrm{F}$. only 6 times. After that, however, the daily maximum temperatures were regularly above $100^{\circ} \mathrm{F}$. Minimum temperature never fell below $55^{\circ} \mathrm{F}$. Evaporation of water from tubs and frequent sprinkling of the floor kept a normal amount of water vapor in the air. Relative humidity was a little below 30 per cent only twice. More often it ranged between 40 and 80 per cent.

Seedlings were counted, recorded, and removed from the plots as quickly as they could be identified. Consequently, none died from competition. Some of the 
common ruderals were readily recognized as early as the cotyledon stage but usually 2 to 3 leaves had developed before the plants were removed. Several of the less common species were allowed to flower before identification could be certain. Most of these plants, especially from western stations, attained maturity so quickly that identification of all but 3 species of minor importance was possible when the study was concluded at the end of July.

Ordinary manuals are of little value for the identification of grass seedlings. Several bulletins and leaflets on vegetative characters of pasture grasses were used. (Copple and Aldous, '32; Keim et al, '32; Harrington, '38). These were helpful sources of information, but check seedlings of most of the common prairie and pasture grasses, grown in boxes in the greenhouse, were the most reliable means of identification. Although distinguishing characters appeared relatively early in grasses, verifications were not made before 3 or more leaves had developed (fig. 7). This is in accordance with Copple and Aldous ('32) who state that the earliest period at which identification by vegetative characters appears practical is after the production of the second blade. When distinction between two species was difficult, plants were carefully lifted to secure the caryopses (sometimes burs) which were still attached to the seminal roots.

\section{Results}

Seedlings of Russian thistle (Salsola pestifer) and pigweeds (Amaranthus spp.) were the first to appear in the plots, and germination of these continued until mid July. The prostrate spurges (Chamaesyce spp.), purslane (Portulaca oleracea), lamb's quarters (Chenopodium spp.), stickseed (Lappula occidentalis), and peppergrass (Lepidium spp.) also germinated promptly. Seedlings of most grasses emerged at the same time or shortly after the ruderal forbs. Germina-

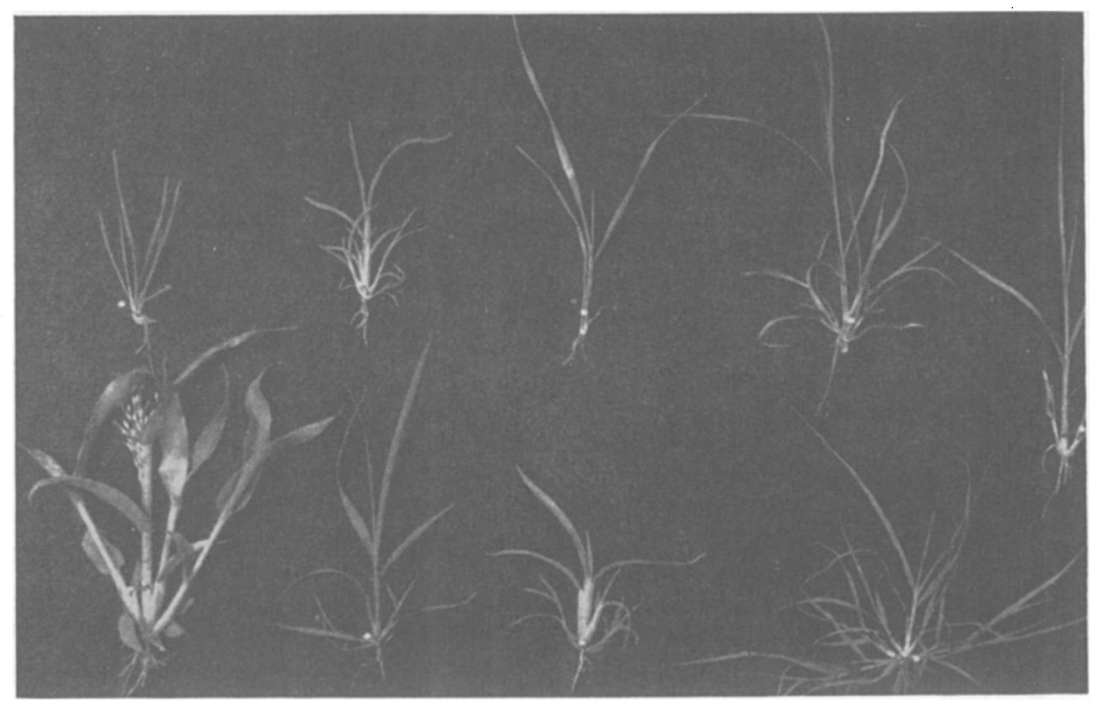

FIG. 7. Seedling grasses three weeks after planting the seed. Left to right in upper row are little barley (Hordeum pusillum), little bluestem (Andropogon scoparius), western wheat grass (Agropyron smithii), side-oats grama (Bouteloua curtipendula), and tall dropseed (Sporobolus asper). Lower row: witchgrass (Panicum capillare), big bluestem (Andropogon furcatus), tumblegrass (Schedonnardus paniculatus), and buffalo grass (Buchloe dactyloides). Plants grown out-of-doors under very favorable environment in July. 


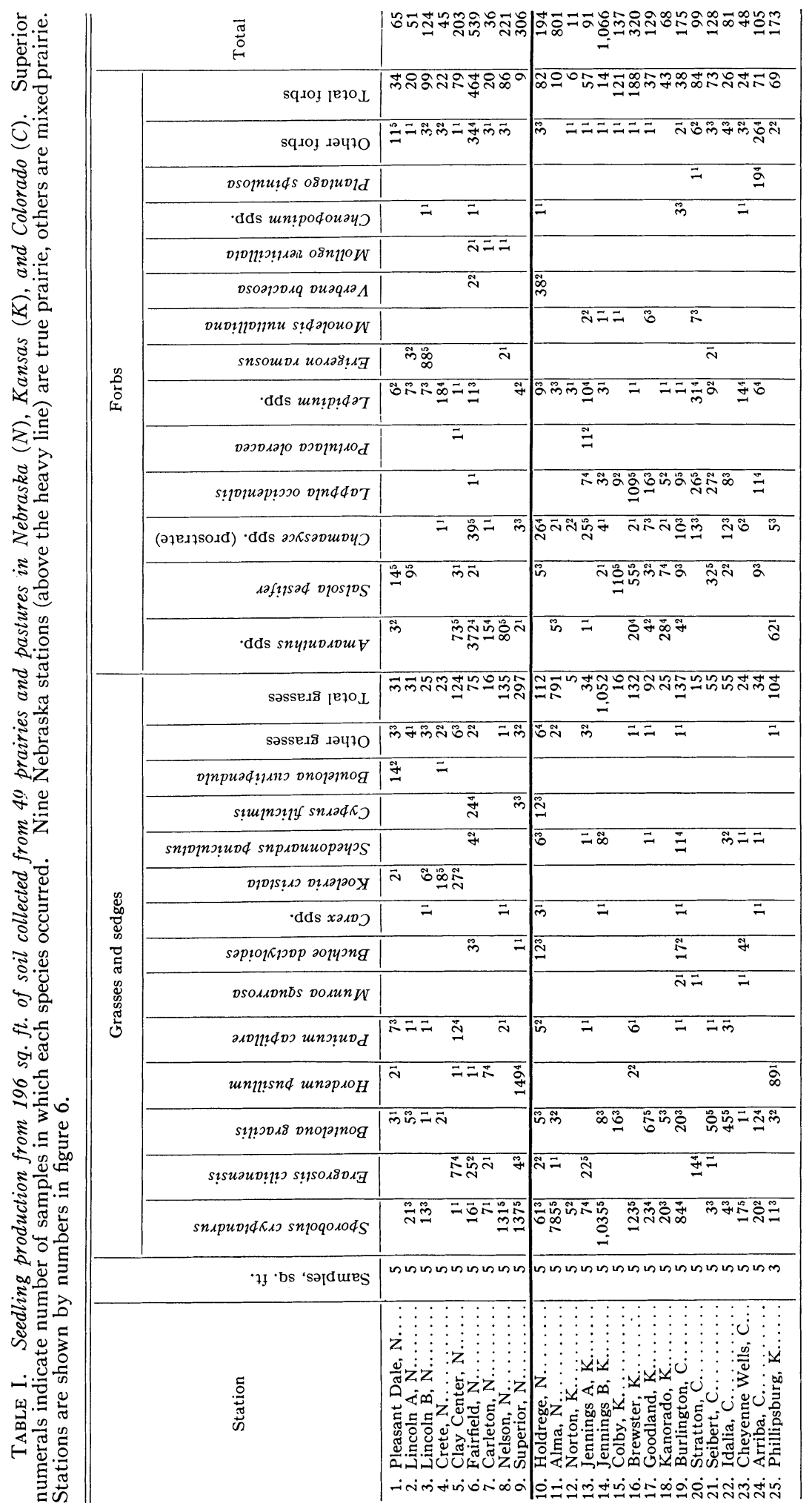




\begin{tabular}{|c|c|c|c|}
\hline & 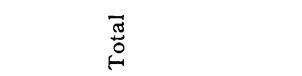 & 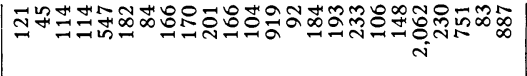 & $\stackrel{\infty}{=}$ \\
\hline & squoj trotol & 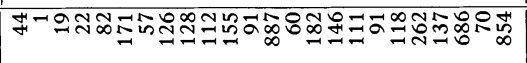 & 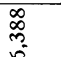 \\
\hline & sqдоу дәчәо & 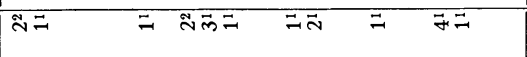 & $m_{i n}$ \\
\hline & psolnu?ds o8pinpld & & $\sin ^{n}$ \\
\hline & dds unıрофоиачว & テニニ デ こら゙ & งก \\
\hline & 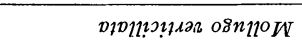 & 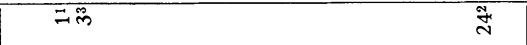 & ల్లా \\
\hline & рรоароля риаqла $\Lambda$ & $\bar{\sim}$ & 30 \\
\hline & 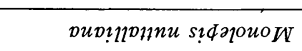 & 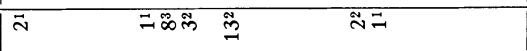 & วกี \\
\hline$\stackrel{n}{2}$ & 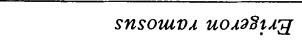 & & nूo. \\
\hline & 'dबs un!p?đaT & 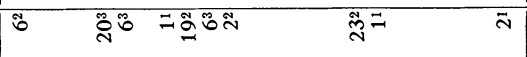 & 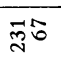 \\
\hline & 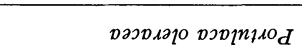 & 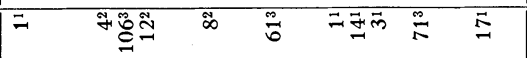 & 일 \\
\hline & 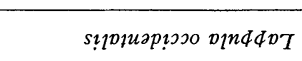 & 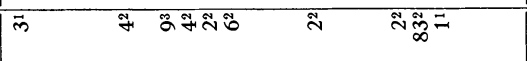 & 笛的 \\
\hline & 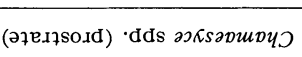 & 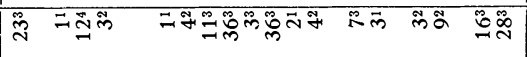 & ర్లై \\
\hline & 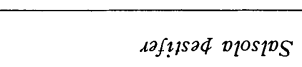 & N = & నిర్ల \\
\hline & 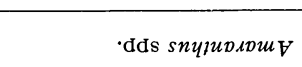 & 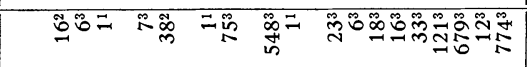 & \#̇ं \\
\hline & səssex I870L & 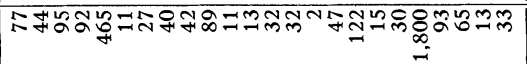 & 惫 \\
\hline & 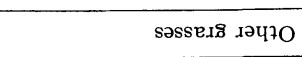 & $\exists=$ & 위요 \\
\hline & 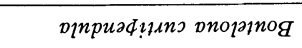 & & nm \\
\hline & s?mนnว!n snıафאכ & $\exists$ & $F \approx$ \\
\hline & snıрипว?ирф sпририиорәчวS & $\bar{\Xi}$ & 99 \\
\hline & 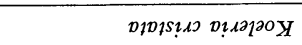 & & in \\
\hline 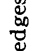 & 'dds $x a$ atv & $\vec{\sim} \quad \vec{z}$ & 52 \\
\hline 吕 & 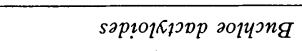 & 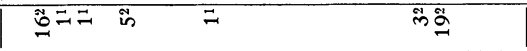 & $\infty \pi$ \\
\hline 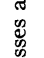 & DSOAdDES DOMUN & 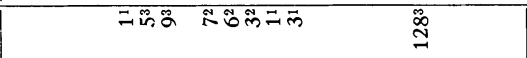 & $\hat{\omega} \underline{\omega}$ \\
\hline 造 & 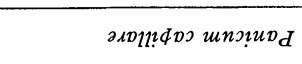 & 总二式 & $\infty \mathbb{\infty}$ \\
\hline & 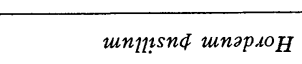 & 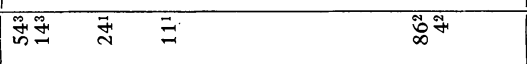 & 亲电 \\
\hline & 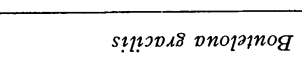 & mo a & $\operatorname{Nin}_{i \rightarrow \infty}^{\infty}$ \\
\hline & 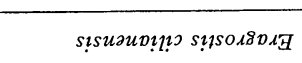 & Oั & givin \\
\hline & 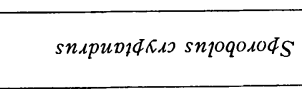 & 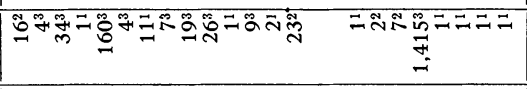 & 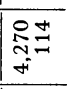 \\
\hline & 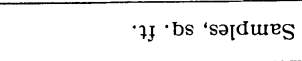 & MMM HMMMMMMMMMMMMMMMMMMMM & 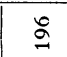 \\
\hline & 总 & 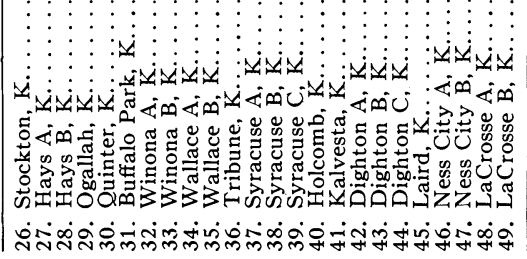 & 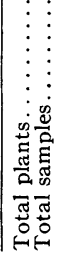 \\
\hline
\end{tabular}


tion of stinkgrass (Eragrostis cilianensis) was delayed several days, however, and that of little barley (Hordeum pusillum) for about 3 weeks. The only grass seeds which germinated abundantly after the soil had been worked over were sand dropseed (Sporobolus cryptandrus), little barley, and stinkgrass.

More than 13,000 seedlings emerged from the 196 samples of soil, an average of nearly 67 plants per square foot (table I). The total number of grass plants $(6,730)$ somewhat exceeded the total number of forbs $(6,388)$, but the number of species of forbs (40) surpassed the species of grasses by 14 . Only 2 samples, both from a severely dusted pasture at Norton, failed to produce any seedlings. Germination from samples collected at Carleton, Crete, Hays A, Lincoln A, and Pleasant Dale were also relatively low. Seed failed to mature at these stations in 1940. Samples from Laird yielded the greatest number of plants, 2,062, an average of 687 per square foot. About 68 per cent of these were sand dropseed.

Certain species of grasses and a sedge - Kocleria cristata, Bouteloua curtipendula, Andropogon scoparius, A. furcatus, Stipa spartea, Eragrostis pectinacea, Echinochloa crus-galli, Agrostis hyemalis, Panicum scribnerianum, Bromus tectorum, and Cyperus filiculmis-were more or less limited to the true-prairie stations (Pleasant Dale, Lincoln, Crete, Clay Center, Fairfield, Carleton, Nelson, and Superior). They exceeded the species common to mixed prairie-Buchloe dactyloides, Schedonnardus paniculatus, Munroa squarrosa, Bouteloua hirsuta, and one unknown-by 6. Sporobolus cryptandrus, Eragrostis cilianensis, Bouteloua gracilis, Hordeum pusillum, Panicum capillare, Festuca octoflora, Setaria spp., and Carex spp. were common to both regions.

Seventy-three per cent of the total number of grass plants consisted of 3 native perennial grasses (Sporobolus cryptandrus, Bouteloua gracilis, and Buchloe dactyloides), all recognized as valuable forage species. This was an average of 25.1 plants per square foot. Sand dropseed alone made up 63 per cent of the grass plants and occurred in 114 samples from 88 per cent of the stations. Blue grama grass (Bouteloua gracilis) appeared in 85 samples and was missing from less than one-third of the stations. Buffalo grass, recorded from only 25 per cent of the stations and 11 per cent of the samples, lacked the uniform distribution of the two preceding grasses. Except for a small number of seedlings of June grass (Koeleria cristata), side-oats grama (Bouteloua curtipendula), big bluestem (Andropogon furcatus), little bluestem ( $A$. scoparius), needle grass (Stipa spartea), and sedges, the remainder consisted of weedy species. Samples from Stratton, Norton, Tribune, Holcomb, and Ness City B failed to produce forage grasses in significant numbers.

Sixteen forbs-Lappula occidentalis, Portulaca oleracea, Monolepis nuttalliana, Plantago spinulosa, Talinum parviflorum, Neomamillaria sp., Opuntia humifusa, Diaperia prolifera, Psoralea tenuiflora, Oxalis stricta, Specularia leptocarpa, Allionia linearis, Proboscidea louisiana, Sisymbrium altissimum, Sophia pinnata, and 1 unknown species-except 1 specimen each of Lappula and Portulaca, were limited to mixed prairie. Only 9 species - Aster multiflorus, Hosackia americana, Specularia perfoliata, Petalostemon sp., Trifolium repens, Veronica xalapensis, Silene antirrhina, Mentha sp., and 1 unknown-were confined to true prairie. Amaranthus spp., Salsola pestifer, Chamaesyce spp., Lepidium spp., Erigeron ramosus, Verbena bracteosa, Mollugo verticillata, and Chenopodium spp. were recorded from samples over the whole area. The scarcity of seedlings of native perennial forbs was noteworthy. More than 96 per cent of the total forbs consisted of annual weeds. In general, more weed seeds germinated in samples from west-central Kansas than from any other 
area, but the production of weeds was also high in samples from Fairfield, which is a true prairie station.

\section{Field Studies}

The ranges from which soil samples for seed germination had been secured were studied between June 10 and 26 . The soil was examined in regard to water content and consequent suitability for seed germination, the composition and development of the vegetation were studied, and the abundance of seedlings was ascertained.

\section{Soil moisture}

The depth of moist soil had been determined at the time the samples were taken and a second survey of the depth of water penetration was now made. On both visits, samplings were made by means of a Briggs geotome at three different places in each range. The deeper soil was so dry that the transition from moist to dry soil was very sharp and readily determined (table II).

Average depth of moist soil, in inches, at stations in west-central Kansas (numbered as on map, fig. 6) was as follows on April 10 to 15: (25) Phillipsburg, 17 ; (26) Stockton, 24; (27) Hays A, 23; (28) Hays B, 22; (29) Ogallah, 22; (30) Quinter, 18; (31) Buffalo Park, 18; (32) Winona A, 9; (33) Winona B, 9; (34) Wallace A, 9; (35) Wallace B, 9; (36) Tribune, 7; (37) Syracuse A, 18; (38) Syracuse B, 18; (39) Syracuse C, 21; (40) Holcomb, 30; (41) Kalvesta, 18; (42) Dighton A, 20; (43) Dighton B, 17 ; (44) Dighton C, 18; (45) Laird, 22; (46) Ness City A, 17; (47) Ness City B, 20; (48) La Crosse A, 20; and (49) La Crosse B, 20.

These data have been supplemented by a study of the precipitation by days from April 1 to June 15 . The study was made from the records of the Weather Bureau at stations near the areas sampled. Twelve such stations were examined in Nebraska, 5 in Colorado, and 20 in Kan-
TABLE II. Minimum and maximum depth in inches to dry soil when samples for germination studies were collected in spring and when seedling surveys were made in early summer. In location of stations by states, Nebraska, Kansas, and Colorado are represented by N., K., and C., respectively. Station numbers correspond to those on the map (fig. 6).

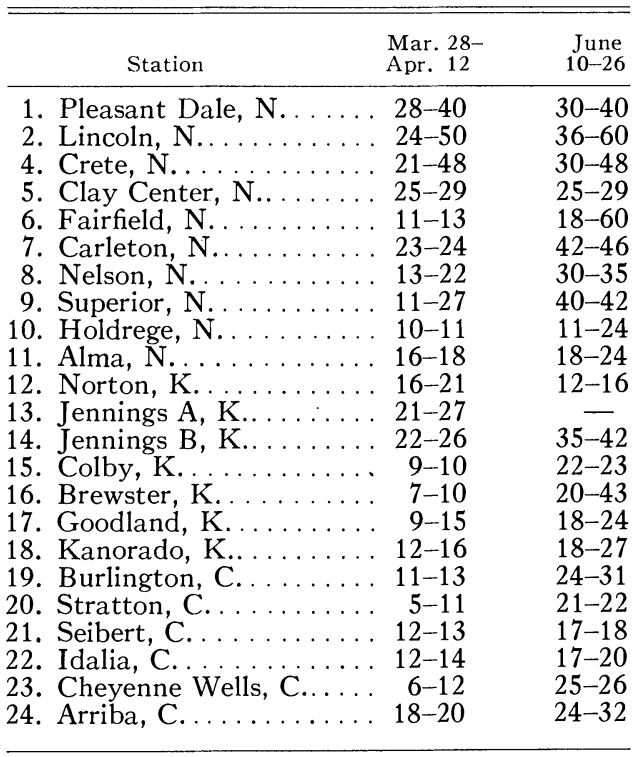

sas. The spring was cool, late, and, like early summer, unusually wet. The total precipitation was not only well above the normal at every station, but often several inches above, and not infrequently two to four times normal. Moreover, the showers were so well distributed that soil moisture was unusually favorable for germination of seeds and establishment of seedlings. Numerous days with a trace of rain or light precipitation indicated much cloudy weather. No prolonged periods of drought occurred. Although the second survey of depth of soil moisture was not made at all stations in westcentral Kansas, repeated observation at the numerous stations showed that moisture was available for growth during the entire spring and early summer.

These data showed conclusively that on practically every range a continuous supply of moisture had been available to promote germination of seeds and establishment of seedlings, a fact which was borne 
out by the excellent development of weeds and other vegetation.

\section{Composition and development of vegetation}

Depleted ranges are usually heavily infested with a diverse population of weeds. In spring especially, they give the appearance of excellent pasturage. Since they greatly affect the establishment of seedling grasses, mention will be made of the more important species.

The annual (often winter annual) little barley was dry and yellowish by June 15 . Dense, continuous stands 3 to 15 inches tall gave many ranges in Nuckolls, Harlan, Phillips, and adjoining counties the appearance of a stubble field or of headed grain. In western Kansas it was found on the more favored sites only, and disappeared almost entirely in Colorado. Little barley is very detrimental to the growth of grass seedlings and established short grasses as well. Like other rapidly growing weeds, it absorbs large amounts of water from the surface soil and produces a thick layer of vegetation which reaches a height of 10 to 16 inches (fig. 8 ). The shade is dense, and the large amounts of dried straw continue to obstruct the light for seedlings and all low growing vegetation. When it lodges, chance for survival of seedlings beneath it is still further reduced. At Phillipsburg, Kansas, in 1940 and 1941 for example, this weed alone produced 1 to 2 tons of forage per acre each year.

Peppergrass (Lepidium densiflorum) formed continuous dense stands over many acres. The plants were about 8 inches tall and grew so thickly that they obscured the grasses beneath. Density of stand always increased with sparseness of the perennial grass cover, which was often only 1 to 3 per cent (figs. 9 and 10). The fallen seeds were sometimes so abundant that they completely covered the soil. Often the leaves of the grasses were splattered with the seeds which are mucilaginous when wet. Newly dried plants were straw-colored, older ones a drab gray. Great alternes on the barer slopes were composed of this weed, and in places they covered the entire pasture. Frequently 160 plants grew on a single square foot. Peppergrass was fairly abundant on the more easterly ranges, grew thickly in more central ones, but westward it was replaced on the bared areas by species of Lappula or Cryptantha.

While young plants of stickseed ( $L a p$ pula occidentalis mostly) were green, they covered the bared soil. On dried plants the leaves had shriveled or fallen and the much-branched stems and spiny fruits only were prominent. Their drab color demarked many areas of a few square feet to many square rods, if indeed it did not give tone to the whole landscape (fig. 11). Beneath this thick weedy growth, usually about 8 inches high, was the depleted stand of grasses, the density of the grass cover usually being inversely proportional to the density of the stand of the weeds. Stickseed was especially abundant in western Kansas and Colorado.

The harsh borage (Cryptantha crassisepala) is often associated with Lappula or alone covers much bared or partly bared soil. These early maturing plants take on a blackish color when they dry.

All of these quickly maturing, weedy plants-little barley, peppergrass, stickseed, and cryptantha-frequently grow even in the best remaining patches of blue grama and buffalo grass, as well as more densely between them. They form either a discontinuous, patchy layer above the grasses or overshadow them entirely throughout the entire range. They are often accompanied by an abundance of six-weeks fescue (Festuca octoflora). They are of little value for grazing and upon drying become highly undesirable. Yet they usually formed the major components of the plant cover. Studies on the yield of ranges in western Kansas, have shown that while a ton per acre of peppergrass, stickseed, Russian thistle, and other weeds was produced, the yield of na- 

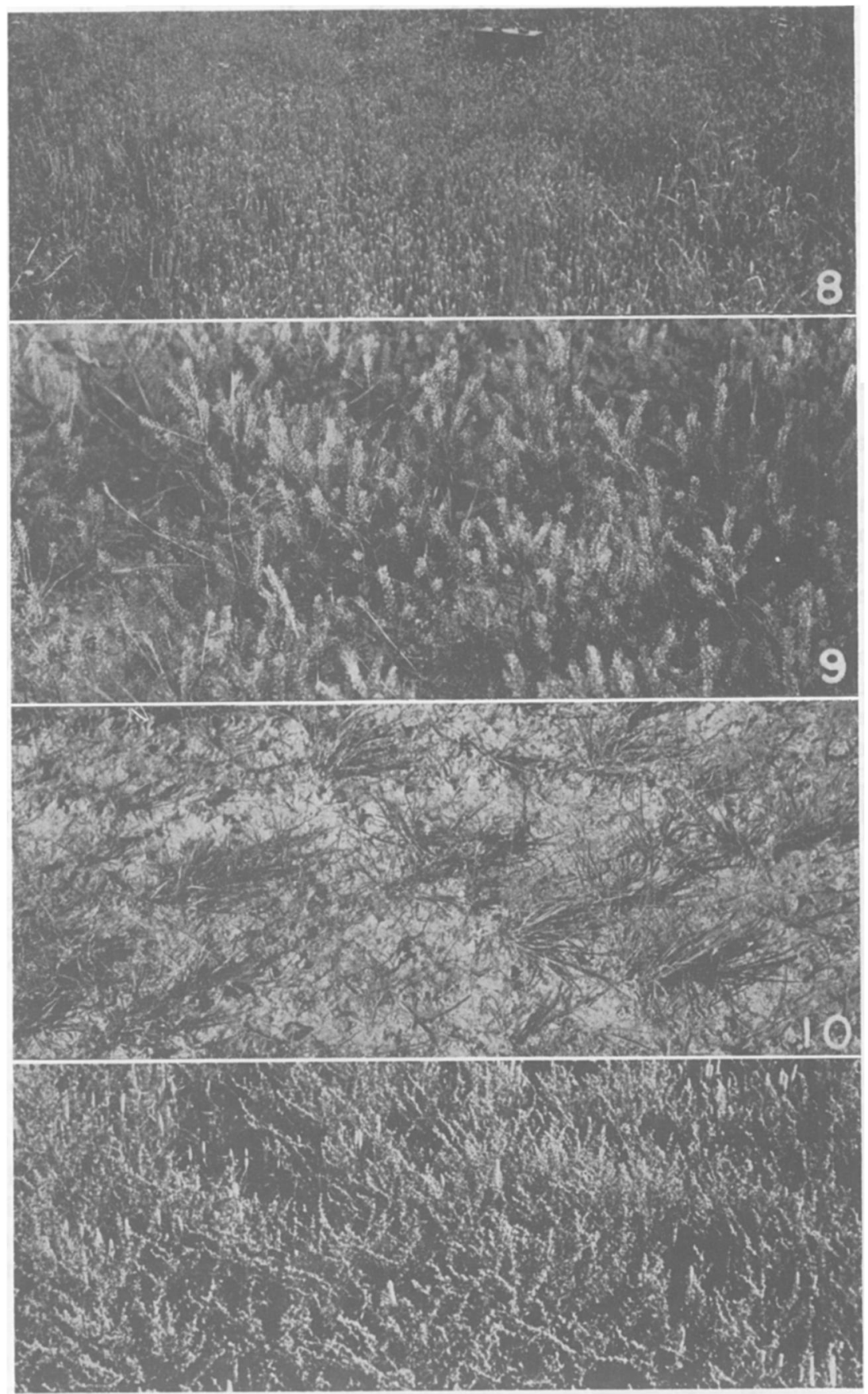

FIG. 8. Little barley 10 inches high in overgrazed pasture at Lincoln, Nebr., June 7, 1939. Fig. 9. Peppergrass 8 inches high near Alma, Nebr., June 16, 1941. Fig. 10. Typical understory of blue grama grass growing under a dense cover of peppergrass which has been removed by pulling up the plants. Cheyenne Wells, Colo. Fig. 11. Dense cover of stickseed (Lappula occidentalis) 8 inches high near Arriba, Colo. A two per cent cover of short grass occurred beneath. Photo, June 19, 1941. 
tive grasses was only a few pounds. ${ }^{3}$ Weeds were abundant generally, but on some Colorado ranges they were few (fig. 12).

The preceding weeds are all well adapted to a dry grassland climate where moist springs are frequently followed by early summer drought. The dominant short grasses and mid grasses are similarly adapted. Flower stalks of Bouteloua gracilis were often 13-15 inches tall by the middle of June and Buchloe dactyloides had flowered and was developing seed. Various species of wire grasses (especially Aristida purpurea) were blossoming where they occurred in the subsere, and sand dropseed was beginning to blossom.

The spring had been too wet and cold for the usual development of Russian thistles. They were greatly injured by late frosts and their growth delayed by cool rainy weather. In most pastures they were few, and in all they were subordinate to the other pasture weeds.

3 Albertson and Weaver, 1941 . Unpublished manuscript.
Responding to the excellent condition of soil moisture, crop plants had made their best development in 15 years, and roadside weeds were correspondingly thrifty. Stolons of buffalo grass were spreading widely where this species remained; blue grama was tillering abundantly, and its flower-stalks and spikes were so plentiful as to give a dark or almost black tone to large intermittent patches in the landscape. On tufts of blue grama only 5 to 6 inches in diameter, 125 to 150 flower stalks had grown, so favorable was the environment. Light yellow patches of flowering staminate buffalo grass showed plainly at a distance, often alternating with blue grama.

Except for the great abundance of weeds and the taller foliage of the perennial grasses, vegetation had changed but little from its greatly deteriorated condition observed in the fall of 1939 (Weaver and Albertson, '40). The most important grasses on the midwestern ranges were blue grama, buffalo grass, and, in places, sand dropseed. In comparison, other grasses occurred only sparingly. In 1939,

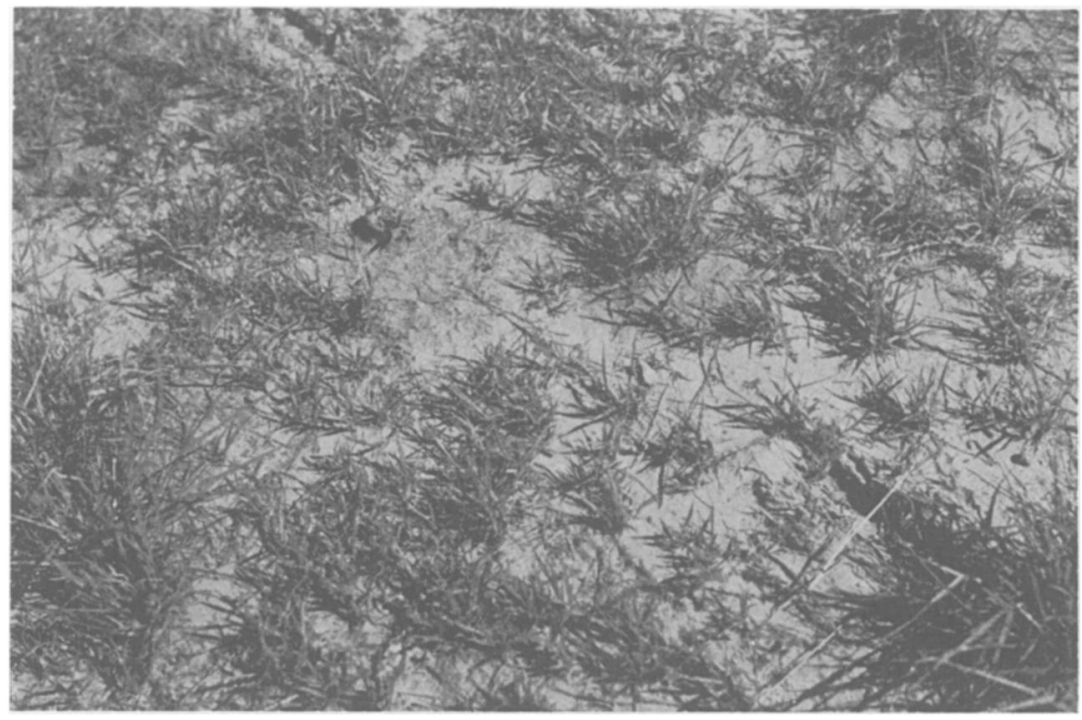

FIG. 12. South slope in a range with few weeds near Burlington, Colo. The bared soil has been naturally reseeded by sand dropseed. Most of the seedlings visible are one or two years old, although young seedlings occurred at the rate of 172 per square foot. Two parent plants are shown in foreground. This was the best reproduction found in any of the ranges examined. 


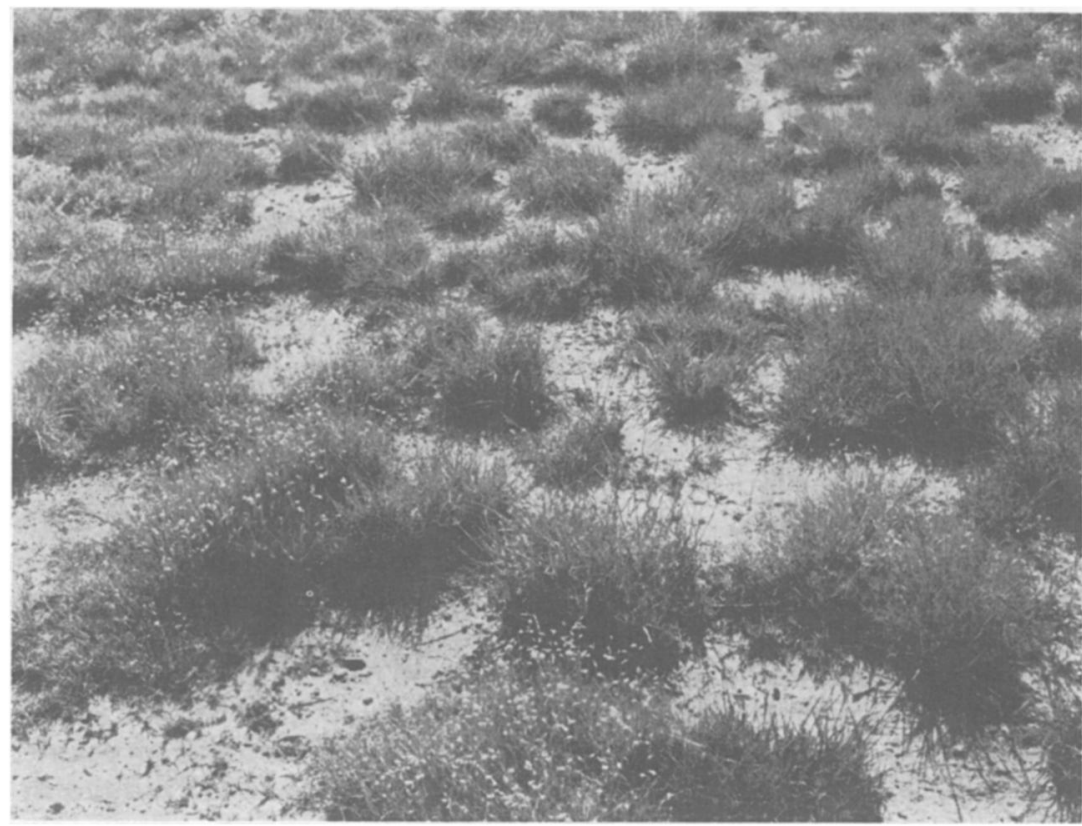

Fig. 13. An excellent ungrazed range of blue grama and buffalo grass in eastern Colorado. Note that the soil has been eroded about the individual bunches. Ruderals are not abundant. Photo, June 19, 1941.

about 10 native perennial forbs could be found on most ranges; some were fairly common. In this suivey, perennial forbs were rare, except sometimes in low ground and in subseres.

In southwestern Kansas, the fall drought of 1939 killed practically all grasses over thousands of acres. Although the ranges recovered slightly in 1940 , they were in no better condition at the end of that year than when described in 1939 (Weaver and Albertson, '40). Although the midwestern ranges appeared greatly improved in 1941, because of the abundance of foliage, many of them had only 1 to 8 per cent cover of perennial grasses. Any improvement since the survey in 1939 amounted to the recovery made in the spring of 1941 . Stock was still excluded from many ranges; numerous other ranges were grazed only lightly. The soil surface was invariably bare and hard, since sandy lands were not included. Nearly all debris had been swept away by wind and water; in fact, very little had been formed during the past eight years of drought. Nearly every bunch or tuft of grass had 0.5 to 1.5 or more inches of top soil eroded from it (fig. 13). There was neither mulch nor shade for seedlings where weeds were few, except those that grew near established plants. There was abundant room for seedlings in all pastures and in all parts of most pastures. Moreover, conditions for growth had been so favorable that no dead seedlings were found.

\section{Survey of seedling population}

Determination of the number of seedlings (June 10 to 26) could not have been well delayed until late in July, since it would have been impossible to distinguish with certainty the previous year's seedlings from those of 1941 . The survey was made by means of determining the number and kind of seedlings in each of 25 square-foot areas taken at random on each range. Selection was made by throwing a hoop, care being taken to in- 
clude samples from each of the different types of vegetation, from areas differently grazed, disturbed by dust burial, and with different slopes, etc.

The results of this survey are given for all of the stations, except those in 13 counties in western Kansas, in table III. Grasses which appeared in very early spring and soon matured-Hordeum pusillum, Festuca octoflora, and Bromus tectorum-were not included in this census. Panicum capillare, Eragrostis cilianensis, and a few other grasses of a weedy nature but longer lived were included with the native perennials. Seedlings of native forbs were rarely found; they are not listed. Actually they played only a small part in the regeneration of the range. Other grasses include a small number of species found infrequently in true prairie only.

Examination of table III shows a decided decrease both in number of species and individuals from true prairie to mixed prairie. Seedlings of the following were found only in the true prairie area: Koeleria cristata, Andropogon scoparius, Bouteloua curtipendula, Panicum scribnerianum, Cyperus filiculmis, Panicum wilcoxianum, Andropogon furcatus, Stipa spartea, Sporobolus heterolepis, Bouteloua hirsuta, Agropyron smithii, and Poa pratensis.

No species occurred in mixed prairie only. Seedlings of four species-Sporobolus cryptandrus, $S$. asper, Bouteloua gracilis, and Buchloe dactyloides-were found more commonly in this western prairie. Those of Schedonnardus paniculatus ranged throughout.

A total of 24 species of seedling grasses were found in the true prairie stations but only 7 in those of mixed prairie. Only two of the stations in true prairie-Fairfield and Superior-were grazed, the others were drought-depleted, ungrazed

TABLE III. Seedlings of grasses and sedges from 25 square-foot samples from each of 22 ranges in southern Nebraska $(N)$, northwestern Kansas $(K)$, and eastern Colorado $(C)$, in June, 1941. Number of samples in which each species occurred is shown by superior numeral. The eight stations above the heavy line are in true prairie; others are in mixed prairie. Stations are shown by number in figure 6.

\begin{tabular}{|c|c|c|c|c|c|c|c|c|c|c|c|c|c|c|c|c|c|c|c|c|}
\hline Station & 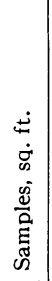 & 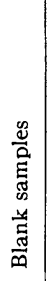 & 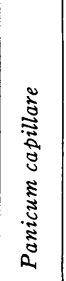 & 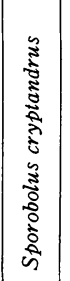 & 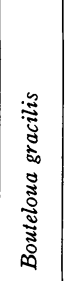 & 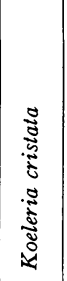 & 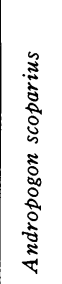 & 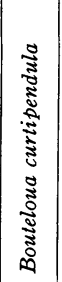 & 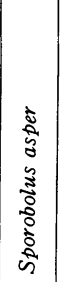 & 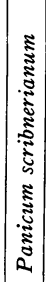 & 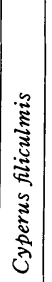 & 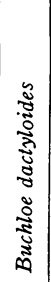 & 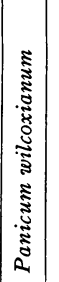 & 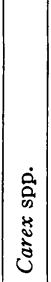 & 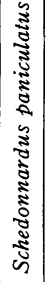 & 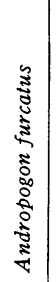 & 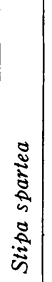 & 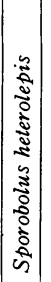 & 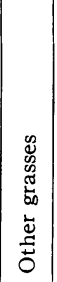 & 胥 \\
\hline 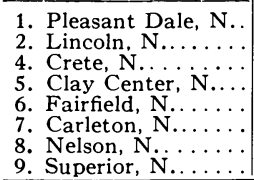 & $\begin{array}{l}25 \\
25 \\
25 \\
25 \\
25 \\
25 \\
25 \\
25\end{array}$ & $\begin{array}{l}3 \\
3 \\
1 \\
6 \\
2 \\
3 \\
3 \\
8\end{array}$ & \begin{tabular}{|r|}
$20^{6}$ \\
\\
$283^{12}$ \\
$313^{19}$ \\
$2^{2}$ \\
$9^{7}$ \\
$3^{3}$ \\
\end{tabular} & \begin{tabular}{|r|}
$1^{1}$ \\
$2^{11}$ \\
62 \\
$34^{10}$ \\
$16^{8}$ \\
$126^{15}$ \\
$54^{10}$
\end{tabular} & \begin{tabular}{r|}
$10^{2}$ \\
\\
$142^{9}$ \\
$14^{7}$ \\
$12^{4}$ \\
$6^{1}$
\end{tabular} & $\begin{array}{r}8^{3} \\
89^{19} \\
34^{11} \\
\\
187^{9}\end{array}$ & $\begin{array}{r}28^{6} \\
31^{13} \\
41^{13} \\
42^{3} \\
26^{9} \\
4^{3}\end{array}$ & $\mid$\begin{tabular}{r|}
$71^{11}$ \\
$19^{5}$ \\
$4^{2}$ \\
$4^{1}$ \\
$10^{1}$ \\
$8^{5}$ \\
$12^{4}$ \\
$26^{5}$
\end{tabular} & $\begin{array}{l}95 \\
1^{1}\end{array}$ & $\begin{array}{r}4^{3} \\
51^{8} \\
19^{4} \\
8^{4} \\
33^{2} \\
2^{1}\end{array}$ & \begin{tabular}{r|}
31 \\
4 \\
4 \\
61 \\
$10^{5}$ \\
11 \\
$61^{3}$
\end{tabular} & $9^{6}$ & \begin{tabular}{|r|}
11 \\
478 \\
11 \\
$15^{4}$ \\
\end{tabular} & \begin{tabular}{|c|}
5 \\
$21^{5}$ \\
$19^{10}$ \\
$4^{4}$ \\
$2^{2}$ \\
$3^{3}$ \\
$1^{1}$
\end{tabular} & $\left|\begin{array}{r}11 \\
15^{5} \\
11 \\
3^{1}\end{array}\right|$ & $\begin{array}{r}1711 \\
1712 \\
4^{3} \\
1^{1}\end{array}$ & $\begin{array}{r}12^{8} \\
4^{3} \\
7^{5}\end{array}$ & {$\left[\begin{array}{l}5^{3} \\
21 \\
9^{2}\end{array}\right]$} & $\mid \begin{array}{r}3^{2} \\
3^{3} \\
53^{13} \\
10^{8} \\
6^{3} \\
3^{3} \\
6^{1}\end{array}$ & $\begin{array}{l}194 \\
242 \\
238 \\
364 \\
530 \\
284 \\
170 \\
169\end{array}$ \\
\hline 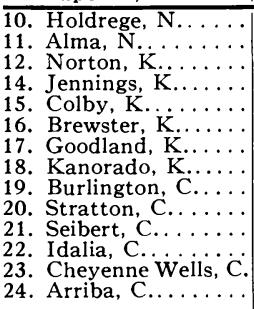 & $\begin{array}{l}25 \\
25 \\
25 \\
25 \\
25 \\
25 \\
25 \\
25 \\
25 \\
25 \\
25 \\
25 \\
25 \\
25\end{array}$ & \begin{tabular}{r|r}
16 \\
5 \\
19 \\
7 \\
22 \\
17 \\
12 \\
13 \\
5 \\
21 \\
5 \\
10 \\
16 \\
6
\end{tabular} & $\begin{array}{l}2^{1} \\
2^{2}\end{array}$ & \begin{tabular}{|r|}
$2^{1}$ \\
$17^{9}$ \\
$7^{3}$ \\
$26^{8}$ \\
11 \\
$42^{7}$ \\
$33^{3}$ \\
$56^{6}$ \\
$152^{9}$ \\
11 \\
11 \\
$15^{7}$
\end{tabular} & \begin{tabular}{r|}
$12^{6}$ \\
$1^{1}$ \\
$42^{10}$ \\
$5^{2}$ \\
$2^{2}$ \\
$40^{11}$ \\
$12^{7}$ \\
$38^{17}$ \\
$3^{1}$ \\
$85^{20}$ \\
$45^{12}$ \\
$1^{1}$ \\
$48^{19}$
\end{tabular} & & & & $89^{8}$ & & & $\begin{array}{r}23^{5} \\
27^{11} \\
3^{3}\end{array}$ & & $2^{2}$ & $\begin{array}{r}2^{2} \\
16^{5} \\
2^{2} \\
10^{4}\end{array}$ & & & & & $\begin{array}{r}30 \\
56 \\
13 \\
158 \\
6 \\
45 \\
75 \\
68 \\
206 \\
6 \\
90 \\
59 \\
20 \\
48\end{array}$ \\
\hline $\begin{array}{l}\text { Total plants. } \\
\text { Total samples }\end{array}$ & 550 & 203 & $\begin{array}{r}634^{\prime} \\
52\end{array}$ & $10 \overline{3}$ & $\begin{array}{l}518 \\
132\end{array}$ & $\begin{array}{r}318 \\
42\end{array}$ & $\begin{array}{r}172 \\
47\end{array}$ & $\begin{array}{r}154 \\
34\end{array}$ & $\begin{array}{r}103 \\
15\end{array}$ & $\begin{array}{l}87 \\
22\end{array}$ & \begin{tabular}{|l|}
85 \\
13 \\
\end{tabular} & $\begin{array}{l}73 \\
34\end{array}$ & $\begin{array}{l}64 \\
14\end{array}$ & $\begin{array}{l}57 \\
32\end{array}$ & $\begin{array}{l}52 \\
24\end{array}$ & $\begin{array}{l}39 \\
27\end{array}$ & $\begin{array}{l}23 \\
16 \\
\end{array}$ & $\begin{array}{r}16 \\
6\end{array}$ & $\begin{array}{l}84 \\
31\end{array}$ & 3071 \\
\hline
\end{tabular}


grassland. But several of the prairies had both fewer species and fewer individuals than the Fairfield pasture.

Although the true-prairie stations include about one-third of the total number, yet 71 per cent of the total seedling population was found here. This is in accord with the more favorable conditions for seed production at these stations during the drought years. Seedlings of sand dropseed and blue grama were the most uniformly distributed. Dropseed occurred in 19 per cent of the samples and at 19 of the 22 stations. Blue grama was found in 24 per cent of the samples and at 18 stations.

Of the 550 square feet of soil carefully examined, 203 square feet (37 per cent of the area) supported no seedlings. Scores of additional areas were examined without delimiting them with a hoop. They gave similar results. Numerous sites above, below, and closely adjacent to clumps of cactus, miniature terraces formed by deposit, depressions, etc., were studied. Bare soil often supported as many seedlings as soil partly covered with debris or vegetation. No relation between erosion and deposit and position of seedlings was found.

Seedlings of perennial grasses were rarely more than 2 inches tall. Many, especially sand dropseed, were only 0.25 inch in height even in mid June. Seed depth of blue grama and buffalo grass ranged from the surface to $0.5 \mathrm{inch}$. The caryopsis was nearly always attached to the base of the seedling. Grass seeds, including buffalo grass, sometimes germinated on the soil surface, or rarely in droppings of jack rabbits. Sometimes seedlings were found lying on the soil surface; others had been partially uprooted by erosion, and still others buried by deposition of soil.

Repeated search for seedling grasses was made by Dr. Albertson during June and early July of 1941 at most of the remaining stations in western Kansas. A few seedlings were observed in the shortgrass habitats at Hays and Phillipsburg; some were found in certain dust-covered areas at Quinter, Dighton, and Ness City; but seedlings were very scarce to absent elsewhere. Many of these ranges had been almost depopulated of native grass, and continued drought had prevented even these relicts from producing viable seed.

\section{Discussion}

There is urgent need for restoration of grass on ranges and abandoned dry land farms. Not only is acute shortage of feed encountered but also without the protective influence of grass the lands are highly susceptible to ruin by erosion. Results from germination studies showed that viable seeds of native perennial forage grasses, with rare exception, were present in such moderate numbers (about 26 per square foot) in soils of depleted pastures as to be of limited value in restoration of the vegetation.

The abundance of seedlings of sand dropseed, both in greenhouse and field studies, are in accord with the records of Weaver and Hansen ('41). They found 84 per cent of the total grass seedlings which appeared in permanent quadrats at Lincoln, Nebraska, during 4 years of protection of a native pasture from grazing, were sand dropseed. The seedlings grew slowly above ground at first but root development during the same period was ample (fig. 14B). This is advantageous in establishment of seedlings especially in regions subject to intermittent drought. Sand dropseed, under optimum conditions, will flower and fruit the first year, thus increasing the seed supply. Optimum conditions, however, occur but rarely within its midwestern range of distribution. Its emergence throughout spring, summer, and far into the fall is also significant. Should the first seedlings succumb to unseasonable weather, others would replace them. This is one reason for its rather wide use in reseeding ranges and abandoned lands. It is possible that viable seeds still remained in the samples of soil when the germination studies were concluded. This may 


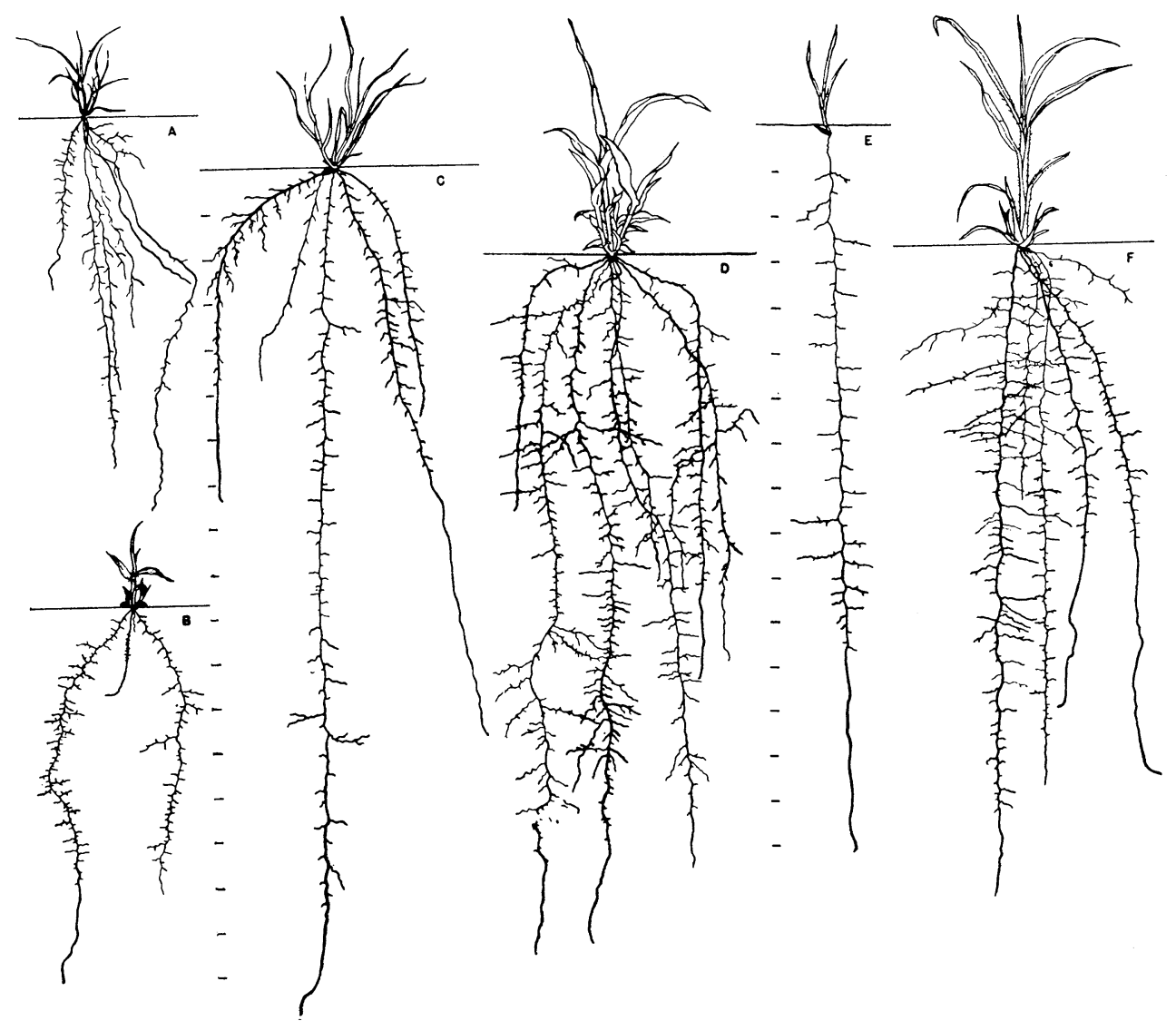

FIG. 14. Seedlings of grasses grown out-of-doors during July in compact, fertile silt loam with approximately optimum water content. Scale in inches. A, Bouteloua gracilis; B, Sporobolus cryptandrus; C, Buchloe dactyloides; D, Panicum capillare; E, Agropyron smithii; and F, Andropogon furcatus. All are 24 days old except B, 18 days and E, 20 days.

have been true of other species as well, since some native grasses germinate better in spring and fall than at other seasons (Blake, '35).

Blue grama grass is one of the best adapted native species for reseeding depleted pastures (Savage, '39). Furthermore, the distribution and number of seedlings and their survival in the field indicate its xeric nature and importance in natural restoration. The spring and early summer of 1941, however, were exceptionally favorable for germination of seeds and survival of seedlings. More often, mortality rate among seedlings is high. Albertson in a communication with the authors stated that he found as many as 50 to 75 short-grass seedlings per square foot at Hays, Kansas, on June 18, 1938. These did well until the drought of midsummer when practically all perished. Even those well established were wilting or had become dormant. By August 1 , myriads of dead seedlings of the short grasses were observed. However, about 1 per cent of widely scattered seedlings of both species survived. Seedlings of buffalo grass had as many as 6 to 8 tillers each, with leaves about 1.5 inches long. Fewer tillers characterized blue grama but the grass was taller. Of the numerous plants excavated, none had roots penetrating the soil to a greater depth than 8 inches. Dead seedlings had 
shorter and more poorly developed roots. When the supply of soil moisture is adequate, blue grama seedlings tiller freely and flower the first season (Mueller, '41).

The percentage of germination of buffalo grass seeds has been found to be rather low (Webb, '41). This, together with poor equipment of the species for dissemination of seeds, accounts in part for fewer seedlings and their more limited distribution. Livestock may be help$\mathrm{ful}$ in disseminating the seeds of buffalo grass (Savage, '39), and the seeds may be lifted by running water and deposited at bases of slopes or in streams (Griffith, '40). But at no time during this study were seedlings found in greater numbers in ravines than elsewhere.

Vegetative propagation by buffalo grass is very efficient and a seedling may populate a bare space quickly if soil moisture is available (Mueller, '41; Webb, '41). Tillering begins 10 to 14 days after emergence, and stolons appear when plants are only a month old. Under very favorable conditions, stolons may elongate at the rate of 0.5 to more than 1.5 centimeters per day, but when drought comes or if the plants are shaded, elongation is curtailed. Growth of tops is paralleled by a vigorous root development (fig. 14C). Adventitious roots appear promptly and penetration often surpasses that of blue grama at the same age (fig. 14A).

Shoots of big bluestem elongate rapidly and develop much foliage. This is advantageous when seedlings are competing for light, but when moisture is a limiting factor the ratio of transpiration to absorption by the roots might be great enough to impede further development or even result in death (fig. 14F). Seedlings of this species were limited to the true prairie where the shortage of soil moisture has been somewhat less acute than in the mixed prairie. Roots of little bluestem reach a depth of 6 inches and have branches of the second order 16 days after the plant appears above ground. Rapid early tillering greatly increases the transpiring surface. Seedlings do not withstand drought as well as those of most of the preceding species (Weaver, '30).

Sparse branching of roots of seedlings of western wheat grass would indicate the necessity for germination of seeds early in spring if the plants were to become established before summer drought (fig. 14E). Panicum capillare requires only a short growing period for completion of its life cycle. It thus escapes drought and may add a new supply of seeds to the soil each year. Roots thoroughly ramified throughout the soil to depths of 12 to 18 inches (fig. 14D), and inflorescences appeared in less than a month. Similar habits of Eragrostis cilianensis contribute to its success in early stages of succession.

The presence of parent plants and their fruitfulness vitally influences the distribution and abundance of seedlings. Certain grasses, which were once important constituents of the prairie, as little bluestem, June grass, needle grass, and bluegrass, either were missing or occurred but sparingly among the seedlings. Mature plants of these species have largely disappeared from the midwestern ranges (Weaver and Albertson, '36, '39, '40).

It is not often that a good seed year precedes a year favorable for germination of seeds and establishment of seedlings. Moreover, vitality of seeds collected from prairie plants differs from season to season and also according to the degree to which the plants are harmed by grazing (Sampson, '14). Climatic conditions at anthesis, available soil moisture, frosts, etc., are important factors. Yield of viable seed during drought years was practically nil in many localities. Yield of caryopses of blue grama grass for west central Kansas in 1939 was about 16 per cent of the normal (Branson, '.41). Blue grama grass, buffalo grass, and sand dropseed flowered at the mixed prairie stations in 1940 , but percentage of yield as compared with the normal is not known. Grasses which flower in summer and autumn were injured by drought at the prairie stations 
in 1940. Consequently, little viable seed was produced.

Owing to local showers, seed may be produced in some parts of the grassland every year. During 1937, a year of less severe drought, some seed ripened at Hays, Kansas, and numerous seedlings were observed in 1938. Most of these were growing in the shade of the tufts of established grasses. They were lighter green and more attenuated than those growing in the open spaces between the bunches. During seasons of good rainfall where foliage development of the established vegetation is good, seedlings growing close to the old clumps often failed to survive. Conversely, during dry seasons when very little foliage is produced, seedlings growing under protection of old plants are far more apt to survive than are those growing in unshaded places between the clumps. Hence the presence of ruderals in overgrazed and dusted pastures is not entirely detrimental. Such plants form a protective covering, thus reducing surface soil evaporation and curtailing erosion.

The probability of the seedlings of such dominant range grasses as blue grama, buffalo grass, and side-oats grama completing their life cycle by production of seed the first year is remote, unless good moisture conditions are rather constantly maintained. A continuous moisture supply rarely occurs in mixed prairie and plains disclimax. Seedlings ordinarily do not survive unless the adventitious roots become established in moist soil. Development of these is largely dependent upon soil moisture. The adventitious roots of seedling grasses of the western ranges require at least 3 to 5 consecutive days with moist surface soil to penetrate sufficiently to become established (Cf. Olmsted, '41; Glendening, '41). But once established they grow rapidly and permit the development of tillers without death by desiccation.

Mortality by drought of even well established seedlings is often high, and great losses occur following germination.
The period of tillering, before new roots become well established in the moist layers of soil, is a very critical one for the plant. The transpiring area has developed somewhat ahead of the root system in contact with deeper soil. Drought at this time often causes great loss. Next to germination it is the most critical time in the life of the plant. For example, hundreds of seedlings of sand dropseed per square foot occurred in the pastures of eastern Nebraska in 1940 when the early autumnal rains terminated the late summer drought. Dry weather again occurred and few survived.

The sparseness or absence of seedlings, except in the best years such as 1938, has been repeatedly observed over a wide area of grassland by Robertson ('39) and R. L. Fowler, ${ }^{4}$ and by the senior author since 1934. Savage ('37), in his extensive quadratting, gives similar results. In June, 1935, 50 miles southwest of Akron, Colorado, he found an average per quadrat of only one seedling each of blue grama and buffalo grass in 20 meter quadrats. In 38 quadrats near Colby, Kansas, the average was 2 and 22 seedlings of these grasses, respectively. At Tribune, Kansas, the average numbers from 40 quadrats were 1 and 27 seedlings, but in other heavily grazed ranges 0 to 3 . When one considers the chances of destruction of seedlings by drought, trampling, grazing by cattle, grasshoppers and rodents, disease, winter killing, etc., such numbers are almost inconsequential.

On the ranges of the southwestern United States, many important forage grasses reproduce from seed only during exceptionally favorable years, although there may continually be a supply of viable seed in the soil (Glendening, '41). This may also prove to be true over large portions of the mixed prairie. It has been the rule during the present period of great drought, and wind and water erosion. Chances for survival of seedlings on wind- or water-moved soil are poorer even than on hard, eroded land. The

\footnotetext{
4 Manuscript, 1941. Unpublished.
} 
transported soil is apt to be moved again, and penetration of rainfall is greatly decreased in recently deposited soil.

Seedlings of grasses were found in only 63 per cent of the sampled areas. Assuming that the perennial grasses had been uniformly distributed, the rate of occurrence would have been 4.3 seedlings per square foot over the whole area. In the mixed prairie the rate was 2.4 seedlings per square foot. Under the most favorable conditions, a seedling (except those of buffalo grass, which were few) would not develop a basal cover of more than one square inch in a single summer. Providing all of the seedlings in mixed prairie lived and grew to this sizè, they would furnish a new cover for somewhat less than 2 per cent of the area. Thus, despite the favorable year, the discrepancy between the greenhouse production of native perennial forage grasses of about 26 per square foot and those found in the field (about 4.3 per unit area) is very great.

It is indeed fortunate that abundant rainfall over most of this grassland in 1941 has promoted excellent seed production. If this is followed by another year conducive to germination, seedling development, and another crop of seeds, revegetation will be greatly promoted. Complete restoration of the former composition and density of the vegetation will require a long period of time and most judicious range management.

\section{SUMMARY}

Square-foot samples of surface soil were collected from 49 drought-damaged ranges and prairies in Nebraska, Kansas, and Colorado, and viable seeds germinated. Seedlings grew at the average rate of 67 per sample. Forty species of forbs occurred, of which more than 96 per cent were annual weeds, mostly Amaranthus spp. and Salsola pestifer. There were 26 species of grass seedlings of which 20 per cent were ruderals, mostly Eragrostis cilianensis, Hordeum pusillum, and Panicum capillare.
Seedling grasses $(6,730)$ slightly exceeded the number of forbs $(6,388)$. More species of grasses grew in samples from true prairie than mixed prairie, but the reverse was true for weedy forbs. Seedlings of native perennial forbs were very few.

Three species of native perennial grasses, Sporobolus cryptandrus, Bouteloua gracilis, and Buchloe dactyloides, all of high forage value, furnished 73 per cent of all the grass seedlings. Seedlings of other perennial grasses were largely confined to prairie stations and were relatively unimportant.

Numbers and kinds of seedling grasses were determined in June in each of 25 square-foot areas in each range or prairie. Extensive soil sampling and study of numerous rainfall records showed that an almost continuous supply of moisture had been available to promote germination and establishment of seedlings.

The rank growth of abundant weeds and much depleted cover of perennial forage grasses were studied in relation to seedling development.

Twenty-four species of seedling grasses were found in true prairie but only 7 in mixed prairie. Mixed prairie included about two-thirds of the places examined but only 29 per cent of the total seedlings were found here.

Of 550 square feet of soil on which seedling grasses were counted, 37 per cent supported none. Seedling grasses were especially rare in drought-stricken and dust-covered ranges of western Kansas.

Seedlings of Sporobolus cryptandrus and Bouteloua gracilis were the most widely distributed and most abundant of those of perennial grasses.

Viable seeds of native perennial forage grasses, with rare exception, were present in such small numbers (26 per square foot) as to be of limited value, when seedling hazards are considered, in restoration of the vegetation.

Average distribution of perennial grass seedlings on the ranges and prairies was 4.3 per square foot; in mixed prairie 
alone, 2.4 per unit area. Even if all seedlings (exclusive of the stoloniferous buffalo grass) had survived and made a maximum growth in mixed prairie, they would have increased the cover less than 2 per cent.

Several years of good seed production and development of seedlings into mature grasses are necessary for the restoration of midwestern ranges.

\section{Literature Cited}

Albertson, F. W. 1941. Studies on the prairies of southwestern Kansas. Trans. Kans. Acad. Sci., 44: 48-57.

Blake, A. K. 1935. Viability and germination of seeds and early life history of prairie plants. Ecological Monog., 5: 405-460.

Branson, L. R. 1941. An analysis of seed production of native grasses during the great drought. Trans. Kans. Acad. Sci., 44: 116-127.

Clements, F. E., and J. E. Weaver. 1924. Experimental vegetation. Carnegie Inst. Wash. Pub. 355.

Copple, R. F., and A. E. Aldous. 1932. The identification of certain native and naturalized grasses by their vegetative characters. Kans. Agr. Exp. Sta., Tech. Bull. 32.

Glendening, G. E. 1941. Development of seedlings of Heteropogon contortus as related to soil moisture and competition. Bot. Gaz., 102: 684-698.

Griffith, D. E. 1940. The collection and processing of buffalo-grass seed. Soil Cons., 6: 132-133.

Harrington, H. D. 1938. Key to some Colorado grasses. Mimeographed leaflet. Colorado State College, Fort Collins, Colo.

Keim, F. D., et al. 1932. The identification of the more important hay grasses of $\mathrm{Ne}$ braska by their vegetative characters. Nebr. Agr. Exp. Sta., Res. Bull. 65.
Mueller, I. M. 1941. An experimental study of rhizomes of certain prairie plants. Ecological Monog., 11: 165-188.

Olmsted, C. E. 1941. Growth and development in range grasses. I. Early development of Bouteloua curtipendula in relation to water supply. Bot. Gaz., 102: 499-519.

Riegel, A. 1941. Life history and habits of blue grama. Trans. Kans. Acad. Sci., 44: 76-85.

Robertson, J. H. 1939. A quantitative study of true-prairie vegetation after three years of extreme drought. Ecological Monog., 9: 432-492.

Sampson, A. W. 1914. Natural revegetation of range lands based upon growth requirements and life history of the vegetation. Jour. Agr. Res., 3: 93-148.

Savage, D. A. 1934. Methods of reestablishing buffalo grass on cultivated land in the Great Plains. U. S. Dept. Agr., Circ. 328.

- 1937. Drought survival of native grass species in the central and southern Great Plains, 1935. U. S. Dept. Agr., Tech. Bull. 549.

- 1939. Grass culture and range improvement in the central and southern Great Plains. U. S. Dept. Agr., Circ. 491.

Weaver, J. E. 1930. Underground plant development in relation to grazing. Ecology, 11: 543-557.

Weaver, J. E., and F. W. Albertson. 1936. Effects of the great drought on the prairies of Iowa, Nebraska, and Kansas. Ecology, 17: 567-639.

- 1939. Major changes in grassland as a result of continued drought. Bot. Gaz., 100: $576-591$.

- 1940. Deterioration of midwestern ranges. Ecology 21: 216-236.

Weaver, J. E., and W. W. Hansen. 1941. Regeneration of native midwestern pastures under protection. Nebr. Cons. Bull. 23.

Webb, J. J., Jr. 1941. Life history and habits of buffalo grass. Trans. Kans. Acad. Sci., 44: 58-75. 